\title{
BINDING OF DEVELOPING MOUSE CEREBELLAR CELLS TO FIBRONECTIN: A POSSIBLE MECHANISM FOR THE FORMATION OF THE EXTERNAL GRANULAR LAYER ${ }^{1}$
}

\author{
MARY E. HATTEN, ${ }^{2}$ MAR'THA B. FURIE, ${ }^{*, 3}$ AND DANIEL B. RIFKIN* \\ Department of Pharmacology and * Department of Cell Biology, New York University School of Medicine, New York, \\ New York 10016
}

Received January 15, 1982; Revised April 9, 1982; Accepted April 12, 1982

\begin{abstract}
The role of the matrix glycoprotein fibronectin in the formation of the external granular layer of the developing mouse cerebellum was investigated by in vitro studies of the binding of cerebellar cells to a fibronectin-coated culture substratum and by in vivo immunocytochemical localization of antiplasma fibronectin antiserum in cerebellar tissue.

The adhesion of cells dissociated from embryonic and early postnatal mouse cerebellum is developmental stage-specific when the cells are plated on tissue culture substrata derivatized with human plasma fibronectin. Cells dissociated from mouse cerebellum at embryonic day 13 form cellular aggregates on insoluble plasma fibronectin. In contrast, cells dissociated from embryonic day 16 through postnatal day 7 cerebellum form a monolayer. Time-lapse video recordings reveal extensive cell movement of late embryonic and early postnatal cerebellar cells on insoluble plasma fibronectin. Late embryonic and early postnatal cerebellar cells bind to fibronectin but do not degrade the fibronectin substratum.

Immunocytochemical studies of the binding of antiplasma fibronectin antisera to cryostat sections of intact embryonic and early postnatal cerebellar tissue reveal a brightly stained region of endogenous fibronectin along the route of granule cell migration from the lateral caudal part of the neuroepithelium lining the fourth ventricle up onto the external surface of the cerebellar anlage. When the formation of the external granular layer is completed, the intense region of fibronectin is no longer visible.
\end{abstract}

In the developing mammalian brain, extensive cell movements and specific cell contacts establish the basic form of the tissue (Sidman and Rakic, 1973). Although the specific cell-cell interactions which appear to guide the final positioning of some neurons have been studied extensively, the mechanisms which guide the large scale cell movements characteristic of early stages of brain histogenesis have not been addressed. One potential guidance system is the extracellular matrix-glycosaminogly-

\footnotetext{
${ }^{1}$ We gratefully acknowledge the expert technical assistance of Ann M. Francois and the critical comments of Drs. Carol A. Mason and M. L. Shelanski. Figure 9 was kindly prepared by Dr. Carol A. Mason. This work was supported by National Institutes of Health Grants NS 15429 (M. E. H.) and CA 23753 (D. B. R.). M. E. H. is the recipient of a Career Scientist Award from the Irma 'T'. Hirschl Charitable 'I'rust.

${ }^{2}$ To whom correspondence should be addressed at Department of Pharmacology, New York University School of Medicine, 550 First Avenue, New York, NY 10016.

${ }^{3}$ Present address: Department of Cellular Physiology and Immunology, The Rockefeller University, 1230 York Avenue, New York, NY 10021.
}

cans and secreted, large cell surface glycoproteins (Toole, 1976).

The cerebellum is one of the easiest brain regions to study, chiefly because it has a limited number of cell types and their sites of origin, pathways of cell migration, and synaptic contacts have been described (Miale and Sidman, 1961; Sidman and Rakic, 1973; Palay and ChanPalay, 1974). The migration of the granule cell, the most numerous neuron in the cerebellum, occurs in two stages. The first stage is a massive movement of proliferative granule cells, beginning at about embryonic day 13 (E13), ${ }^{4}$ anteromedially from the lateral caudal portion of the cerebellar neuroepithelium, where they are gener-

\footnotetext{
${ }^{4}$ The abbreviations used are: AbCIG, antiserum against human coldinsoluble globulin (plasma fibronectin); BME, basal medium, Eagle's; BSA, bovine serum albumin; CIG, human cold-insoluble globulin (plasma fibronectin); E13 and E16, embryonic days 13 and 16; FITC, fluorescein isothiocyanate-conjugated; $\mathrm{P} 0, \mathrm{P} 3, \mathrm{P} 4, \mathrm{P} 5$, and $\mathrm{P} 7$, postnatal days $0,3,4,5$, and 7 ; PBS, phosphate-buffered saline ( $0.2 \mathrm{M}$ phosphate); TCA, trichloroacetic acid.
} 
ated, onto and across the external surface of the cerebellar anlage. By birth, a thin layer of external granule cells (EGL) populates the external surface of the cerebellum (Miale and Sidman, 1961; Sidman and Rakic, 1973; Altman and Bayer, 1978).

The second stage occurs postnatally. Individual, postmitotic external granule cells leave the EGL and descend into the deeper layers of the cortex, apparently using Bergmann glial fibers as a guide (Rakic, 1971; Rakic and Sidman, 1973; Levitt and Rakic, 1980). Although the second stage has been well studied, the mechanism that guides the emerging precursor granule cells from the rhombic lip onto the outer pial surface of the cerebellar anlage is not known.

Cellular fibronectin is a major surface glycoprotein of a wide variety of non-neuronal cells (Hynes, 1976; Yamada and Olden, 1978; Vaheri and Mosher, 1978; Pearlstein et al., 1980; Schachner et al., 1978) which promotes cell adhesion and cell spreading (Yamada and Kennedy, 1979; Rauvala et al., 1981). Plasma fibronectin (CIG) is similar to cellular fibronectin in electrophoretic mobility, subunit structure, and composition (Balian et al., 1979; Vuento et al., 1977; Alexander et al., 1978, 1979) and is immunologically indistinguishable from cellular fibronectin by cross-inhibition assays (Balian et al., 1979; Ruoslahti and Vaheri, 1975). Both fibronectins promote the adhesion of baby hamster kidney cells to tissue culture substrata (Yamada and Kennedy, 1979).

The present study analyzes the mechanisms involved in the initial formation of the cerebellar external granular layer. The efficacy of insoluble plasma fibronectin as a substrate has been evaluated for the adhesion of cells dissociated from mouse cerebellum at developmental stages just prior to, during, and immediately after the formation of the EGL. In addition, immunocytochemical localization of fibronectin in vivo, previously reported for postnatal and adult cerebellum (Schachner et al., 1978; Minier et al., 1981), has been carried out with embryonic and early postnatal cerebellar tissue to determine whether endogenous fibronectin is present along the route of precursor granule cell movement.

\section{Materials and Methods}

Coupling of plasma fibronectin to microwell surfaces. Plasma fibronectin was isolated as described (Furie and Rifkin, 1980) and coupled to Microtest Plate I microwell culture plate surfaces (Falcon, No. 3034) with carbodiimide (1-cyclohexyl-3-(2-morpholinoethyl)-carbodi-imide metho-p-toulenesulfonate) by the procedure described for lectins (Hatten and Francois, 1981). In brief, an aqueous solution of carbodi-imide $(100 \mu \mathrm{g} / \mathrm{ml})$ containing fibronectin $(10$ to $100 \mu \mathrm{g} / \mathrm{ml})$ was added to each microwell $\left(10 \mu \mathrm{l}, \mathrm{pH} 6.5,20^{\circ} \mathrm{C}, 2 \mathrm{hr}\right)$; the plates were washed three times with distilled water, air-dried, sterilized by short wave ultraviolet irradiation (30 to $60 \mathrm{~min}$, $20^{\circ} \mathrm{C}$ ), and used immediately for cell culture assays.

${ }^{125}$ I-Plasma fibronectin was prepared by the chloramine $\mathrm{T}$ method (Freeman, 1967) and was separated from free ${ }^{125}$ I by chromatography with Sephadex G-25 and by dialysis. The specific activity of labeled plasma fibronectin was $1.2 \times 10^{4} \mathrm{cpm} / \mu \mathrm{g}$. The amount of ${ }^{125} \mathrm{I}$-labeled fibronectin coupled to the tissue culture substratum was measured by the method described for lectins (Hatten and Francois, 1981). The amount of ${ }^{125} \mathrm{I}$-fibronectin released from the substratum into the culture medium or into cerebellar cell cultures was assayed as described for lectins (Hatten and Francois, 1981). Precipitation with trichloroacetic acid (TCA, 10\% in bovine serum albumin (BSA), $1 \mathrm{mg} / \mathrm{ml}, 30 \mathrm{~min}, 4^{\circ} \mathrm{C}$ ) was carried out to quantitate the fraction of counts bound to protein.

Cerebellar cell cultures. All studies were carried out with C57BL/6J mice derived from a breeding colony in this department. Females were checked daily for the presence of vaginal plugs; the day of impregnation was E0. Cell culiure experinents were carried out with cerebellar tissue from embryonic days 13 and 16 (E13 and E16) and from postnatal days 0 (P0, birth), 3 (P3), 4 (P4), 5 (P5), and 7 (P7). The majority of the experiments were carried out with E13, P0, and P7 cerebellar tissue.

Cerebellar tissue was removed by dissection and single cell suspensions were prepared as described (Hatten and Sidman, 1978; Hatten and Francois, 1981). In some experiments, cells were plated in medium lacking serum or in medium supplemented with serum that had been depleted of CIG by gelatin affinity chromatography (Furie and Rifkin, 1980). The final plating density was 0.8 to $2.5 \times 10^{6}$ cells $/ \mathrm{ml}$. Cell viability prior to plating was $\geq 85 \%$ as measured by exclusion of the dye trypan blue $(0.4 \%$, Grand Island Biological Co.).

Two parameters were measured in each experiment. First, plating efficiency was measured as described (Hatten and Francois, 1981), and second, cell attachment was assessed by phase contrast microscopy.

For each experiment, three controls (6 microwell cultures each) were carried out. Cells were plated on untreated microwell surfaces, microwell surfaces treated with carbodi-imide $(100 \mu \mathrm{g} / \mathrm{ml})$ or microwell surfaces treated with poly-D-lysine (Hatten and Sidman, 1978). In some experiments, cells were plated on microwell surfaces treated with plasma fibronectin $(50 \mu \mathrm{g} / \mathrm{ml})$ in the absence of carbodi-imide.

Specific inhibition of cell attachment to fibronectincoated surfaces was measured by plating cells in the presence of antiserum raised against plasma fibronectin or against bovine serum albumin $(1: 10,1: 50,1: 100,1: 500$, $1: 1000$, or $1: 2000$ dilution). In some experiments, the antiserum (AbCIG) was added to the culture medium. In other experiments, AbCIG (1:100 or 1:50) was added to fibronectin-coated wells for $2 \mathrm{hr}$ at $35.5^{\circ} \mathrm{C}$; the plate was washed three times with phosphate-buffered saline (PBS) to remove unbound AbCIG and used for adhesion experiments. In other experiments, the cell suspension was agitated gently in medium supplemented with AbCIG (1:50 or 1:100) for $2 \mathrm{hr}$ at $35.5^{\circ} \mathrm{C}$, washed three times with PBS, and plated on a fibronectin-coated $\mathrm{mi}$ crowell surface. In all experiments, some wells were plated with cells suspended in medium supplemented with AbCIG and other wells were plated with cells suspended in medium lacking AbCIG.

In total, more than 20 litters of embryos and 75 postnatal animals were studied. More than 500 microwell cultures were carried out to assay cerebellar cell adhesion to fibronectin-coated microwell surfaces.

In vitro cell migration assay. Cell migration on plasma 
fibronectin-derivatized culture substrata was assayed by time-lapse video recording. A Leitz Diavert microscope fitted with fiber optic illumination was mounted in a Plexiglas chamber fitted with a Yellow Springs Instruments (model 22) proportional temperature controller. Humidity was $100 \%$. An RCA TC 1005 television monitor was mounted on the microscope and time-lapse (1:108) recordings were made with a Panasonic (NV8030) recorder and time-date generator (VICON).

For migration assays, cells dissociated from E16, P0, P4, or P7 cerebellar tissue were plated in Eagle's basal medium (BME) with Hanks' salts (Flow Laboratories, McClean, VA) and HEPES buffer (10 mM, Sigma, St. Louis, MO).

Preparation of antiserum against plasma fibronectin. Human plasma fibronectin (CIG) was purified by gelatin affinity chromatography as described (Furie and Rifkin, 1980 ) and by sodium dodecyl sulfate-gel electrophoresis. The plasma fibronectin band $\left(M_{\mathrm{r}}=250,000\right)$ was cut out of the gel, mixed with Freund's complete adjuvant, and injected into rabbits. Antisera against plasma fibronectin (AbCIG) gave a single line of identity against CIG in immunoelectrophoresis tests (data not shown). To assess the specificity of AbCIG for immunocytochemical procedures, the antiserum (1:100) was absorbed with CIG $(200 \mu \mathrm{g} / \mathrm{ml})$ overnight at $4^{\circ} \mathrm{C}$.

Immunocytochemical procedures. Postnatal mice were killed by decapitation and the whole brain was removed and frozen on dry ice. Whole embryos were removed and frozen on dry ice. Sagittal sections (6 to $8 \mu \mathrm{m})$ of E13 to P7 cerebellum were cut with an American Optical cryostat and thawed onto gelatin-coated slides. Sagittal sections of adult cerebellum were thawed onto untreated slides.

Sections were fixed in paraformaldehyde (4\% in PBS, $\left.30 \mathrm{~min}, 20^{\circ} \mathrm{C}\right)$, pretreated with goat serum $(1: 10,100 \mu \mathrm{l}$, $\left.30 \mathrm{~min}, 20^{\circ} \mathrm{C}\right)$, washed three times with PBS $(100 \mu \mathrm{l}, 10$ $\min , 20^{\circ} \mathrm{C}$ ), and treated with antiplasma fibronectin rabbit antibody $\left(1: 100,30 \mathrm{~min}, 20^{\circ} \mathrm{C}\right)$. The antibody was removed and the sections were washed three times $(100$ $\mu \mathrm{l}$ of PBS, $10 \mathrm{~min}, 20^{\circ} \mathrm{C}$ ) prior to the addition of fluorescein isothiocyanate-conjugated goat anti-rabbit antiserum $\left(100 \mu \mathrm{l}, 1: 200,30 \mathrm{~min}, 20^{\circ} \mathrm{C}\right)$. The sections were washed three times with PBS $\left(100 \mu \mathrm{l}, 10 \mathrm{~min}, 20^{\circ} \mathrm{C}\right)$ and a coverslip was mounted in polyvinyl alcohol $(16 \% \mathrm{w} / \mathrm{v}$, type III, Sigma, St. Louis, MO) in $33 \%(\mathrm{v} / \mathrm{v})$ glycerol (PBS containing $0.1 \%$ sodium azide), final $\mathrm{pH}$ 7.2. All steps were carried out in a humidified chamber.

Specific inhibition of antiplasma fibronectin antiserum binding was measured by treating sections either with antiserum (1:100) preabsorbed with plasma fibronectin $\left(200 \mu \mathrm{g}, 12 \mathrm{hr}, 4^{\circ} \mathrm{C}\right)$ or with preimmune serum. Nonspecific staining from goat serum was assessed by adding FITC goat anti-rabbit serum to sections treated as described except that the addition of anti-fibronectin antiserum was omitted.

We grossly oriented the cerebellum in cryostat sections of early embryonic tissue with phase contrast microscopy by locating the spinal cord and following the embryo rostrally until the choroid plexus, a structural landmark of the ventricular face of the cerebellar anlage, was located. The binding of AbCIG was visualized with epi- fluorescent illumination of the section. In cryostat sections of late embryonic and early postnatal animals, the cerebellum was located by phase contrast microscopy and the binding of $\mathrm{AbCIG}$ was visualized with epifluorescent illumination.

Fluorescence was measured with a Leitz Ortholux microscope fitted with a Zeiss $\times 25$ Plan Neofluor (numerical aperture, 0.8 ) water-oil immersion lens, epifluorescence illumination, an RCA image intensifier camera (RCA TC 1030H), and an Ikegami television monitor. Measurements were recorded with a Panasonic video tape recorder (model NV8030). All photographs were made from video tape recordings displayed on the television monitor ( $1 \mathrm{sec}, \mathrm{f} / 18$, Kodak panatomic film, ASA $32)$.

\section{Results}

Developmental stage-specific attachment of cerebellar cells to fibronectin. As reported earlier (Hatten and Sidman, 1978; Trenkner and Sidman, 1977), embryonic and postnatal cerebellar cells do not adhere to untreated microwell surfaces or other tissue culture plastic surfaces. In contrast, cells dissociated from embryonic and early postnatal mouse cerebellum form a monolayer on polylysine-treated substrata. 'The question then was raised as to whether cerebellar cells would adhere to natural matrix components, such as fibronectin.

The attachment of cerebellar cells to insoluble plasma fibronectin was developmental stage-specific. Cells dissociated from cerebellar tissue harvested on embryonic day 13 (E13) formed cellular aggregates of 500 to 2000 cells each (Fig. 1a). No fiber outgrowth was observed between cellular aggregates. When plated on fibronectin, cell viability was low ( 25 to $35 \%$ ), and after 48 to $72 \mathrm{hr}$, extensive cell death was observed by phase contrast microscopy. The poor survival of E13 cells on fibronectin was consistent with E13 cell behavior on other substrata which do not support their adhesion (Hatten, 1981; Hatten and Francois, 1981).

In contrast, cells dissociated from cerebellar tissue harvested between embryonic day 16 (E16) and postnatal day 7 (P7) formed a monolayer with $95 \%$ plating efficiency on insoluble plasma fibronectin (Fig. $1, b$ and $c$ ). At plating densities between 0.8 and $1.2 \times 10^{6}$ cells $/ \mathrm{ml}$, a monolayer covering 20 to $30 \%$ of the surface area of the microwell was formed. At 1.5 to $2.5 \times 10^{6} \mathrm{cells} / \mathrm{ml}$, the cells formed a confluent monolayer with occasional small cellular aggregates and other areas of sparse cell density. Process outgrowth was extensive after $24 \mathrm{hr}$ in vitro. When the medium was changed every 3 days, cell viability was greater than $90 \%$ for periods up to 2 weeks in vitro. No significant cell proliferation was observed.

To assess the contribution to cell attachment of the soluble fibronectin in the serum relative to the fibronectin bound to the microwell surface, the cells were plated on a fibronectin-coated substratum in medium supplemented with whole serum, in medium supplemented with serum depleted of CIG by gelatin chromatography, or in medium supplemented with both whole serum and free CIG (10 to $500 \mu \mathrm{g} / \mathrm{ml}$, final concentration in growth medium). For all developmental stages, the presence of plasma fibronectin in the growth medium did not influ- 

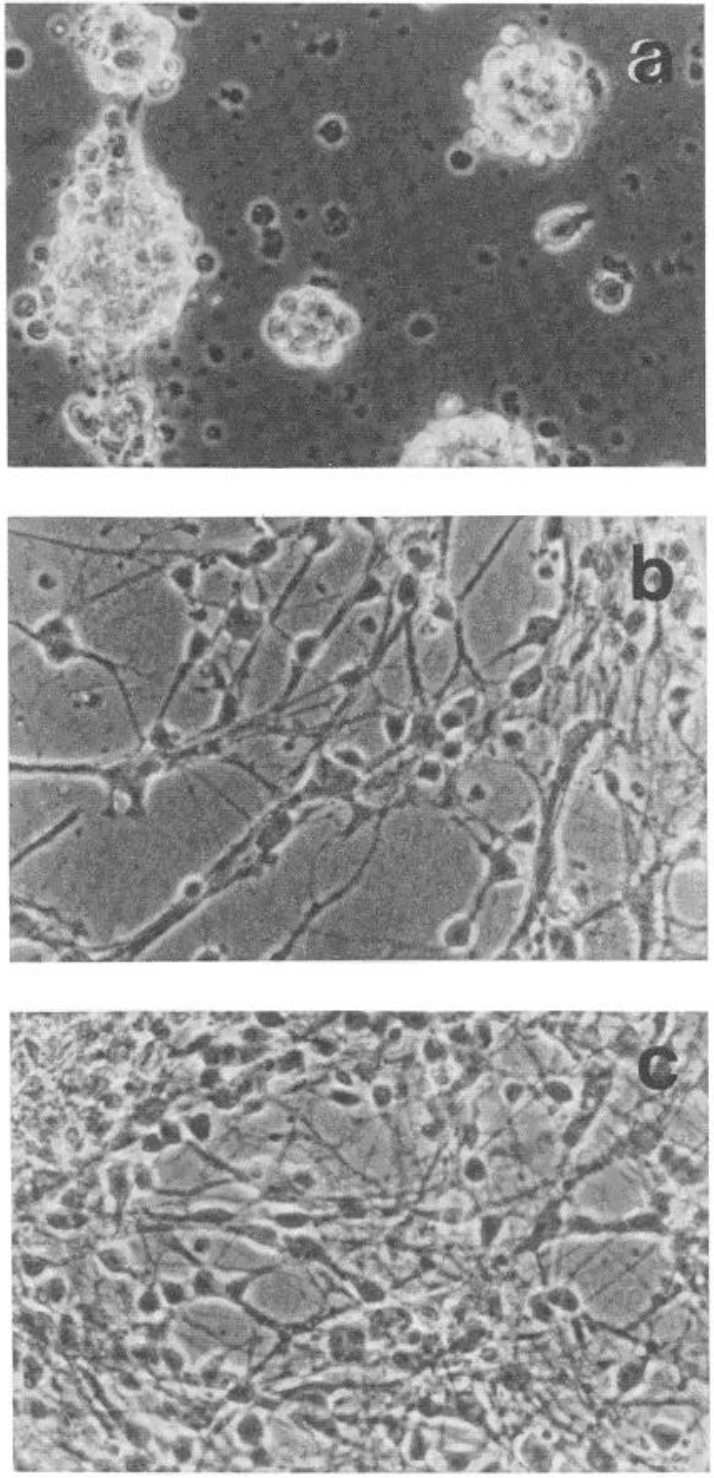

Figure 1. Developmental stage-specific adhesion of cerebellar cells to fibronectin after $48 \mathrm{hr}$ in vitro. Microwells were treated with plasma fibronectin $(50 \mu \mathrm{g} / \mathrm{ml})$ and carbodi-imide $(100 \mu \mathrm{g} /$ $\mathrm{ml})$, and single cell suspensions $\left(1.5 \times 10^{6} \mathrm{cells} / \mathrm{ml}\right)$ of cells dissociated from $(a) \mathrm{E} 13,(b) \mathrm{P} 0$, and $(c) \mathrm{P} 7$ cerebellum were plated as described. Magnification $\times 160$.

ence the attachment and spreading of cerebellar cells on a fibronectin-coated substratum.

The fact that soluble fibronectin did not affect cell adhesion is consistent with other studies that showed in general that, although cells attach to and spread on insoluble fibronectin surfaces, there is very little, if any, specific binding of plasma fibronectin in solution (Yamada and Kennedy, 1979). Preliminary experiments with postnatal cerebellum in vitro indicate that these cells also do not exhibit specific binding of plasma fibronectin in solution (M. E. Hatten, unpublished observation).

The time course of cell attachment to fibronectin was similiar to that reported for cell attachment to carbohydrate and lectin substrata (Hatten, 1981; Hatten and Francois, 1981). Within 2 to $4 \mathrm{hr}$ of plating, E13 cells aggregated and E16, P0, P3, P5, or P7 cells attached to the substratum. In the latter cultures, fiber outgrowth had commenced within $12 \mathrm{hr}$ of plating.

The attachment of late embryonic and early postnatal cerebellar cells to fibronectin depended on the concentration of fibronectin used to treat the microwells. On untreated microwell surfaces, little or no cell attachment and spreading was observed and large cellular aggregates formed (Fig. $2 a$ ). When microwells were treated with 10 $\mu \mathrm{g} / \mathrm{ml}$ of fibronectin, cellular aggregates formed and very little cell spreading was observed (Fig. $2 b$ ). At $25 \mu \mathrm{g} / \mathrm{ml}$, some cellular aggregates were seen and some spreading was observed (Fig. 2c). At 50 to $100 \mu \mathrm{g} / \mathrm{ml}$, a monolayer formed (Fig. 2d).

To determine how much of the fibronectin used to treat the microwell surface actually was bound to the dish, the binding of ${ }^{125} \mathrm{I}$-fibronectin was measured (Fig. 3 ). The amount of ${ }^{125} \mathrm{I}$-fibronectin bound to the culture surface increased with the amount of ${ }^{125} \mathrm{I}$-fibronectin used to treat the culture dish and reached a plateau at 50 to $100 \mu \mathrm{l} / \mathrm{ml}$, the concentration range which promoted the attachment and spreading of late embryonic and early postnatal cerebellar cells. When the plates were treated with $50 \mu \mathrm{l} / \mathrm{ml}$ of ${ }^{125} \mathrm{I}$-fibronectin, approximately $1 \mu \mathrm{g}$ of fibronectin was bound per $100 \mu \mathrm{m}^{2}$, the surface area of a microwell.

To assess whether the ${ }^{125} \mathrm{I}$-fibronectin would remain bound to the microwell surface for the long time periods desirable for some cell culture studies, dishes coated with ${ }^{125} \mathrm{I}$-fibronectin were incubated in the absence of cells in complete BME medium supplemented as described with $10 \%$ horse serum. After $48 \mathrm{hr}$ or 1 week, the amount of ${ }^{125}$ I-fibronectin which remained bound to the microwell surface was assayed by removing the medium and counting with a Gamma counter, air-drying the microwell, cutting it out, and counting with a Gamma counter. The amount of fibronectin bound to the microwell was given as the percentage of total counts bound to the microwell. After $48 \mathrm{hr}, 10$ to $15 \%$ of the bound fibronectin had been released, and after 1 week, more than $50 \%$ of the fibronectin bound to the microwell had been released. This result may relate to the finding by Akers et al. (1981) that the binding of fibronectin to tissue culture plastic is $\mathrm{pH}$ dependent. They reported that significantly more fibronectin is bound at $\mathrm{pH} 6.5$ than at $\mathrm{pH} 7.2$, the $\mathrm{pH}$ of the culture medium. Thus, $\mathrm{pH} 7.2$ may contribute to the leakage of fibronectin from the microwell.

To improve the stability of the binding of fibronectin to the microwell surface, the microwells were treated with fibronectin in the presence of carbodi-imide $(100$ $\mu \mathrm{g} / \mathrm{ml}$ ), an agent which cross-links proteins to plastic by a noncovalent mechanism (Edelman and Rutishauser, 1974).

After $2 \mathrm{hr}$, the amount of fibronectin bound to the microwell in the presence or absence of carbodi-imide was equivalent (Fig. 3). However, the longevity of the binding of the ${ }^{125}$ I-fibronectin to the microwell surface was improved significantly by co-treating the dish with carbodi-imide. When microwell surfaces treated with carbodi-imide and ${ }^{125} \mathrm{I}$-fibronectin were incubated with complete BME medium supplemented with $10 \%$ horse serum, only $5 \%$ of the counts were released after $48 \mathrm{hr}$ (Fig. 4). After 1 week, $90 \%$ of the ${ }^{125}$ I-fibronectin remained bound to the tissue culture surface. Thus, carbodi-imide ap- 

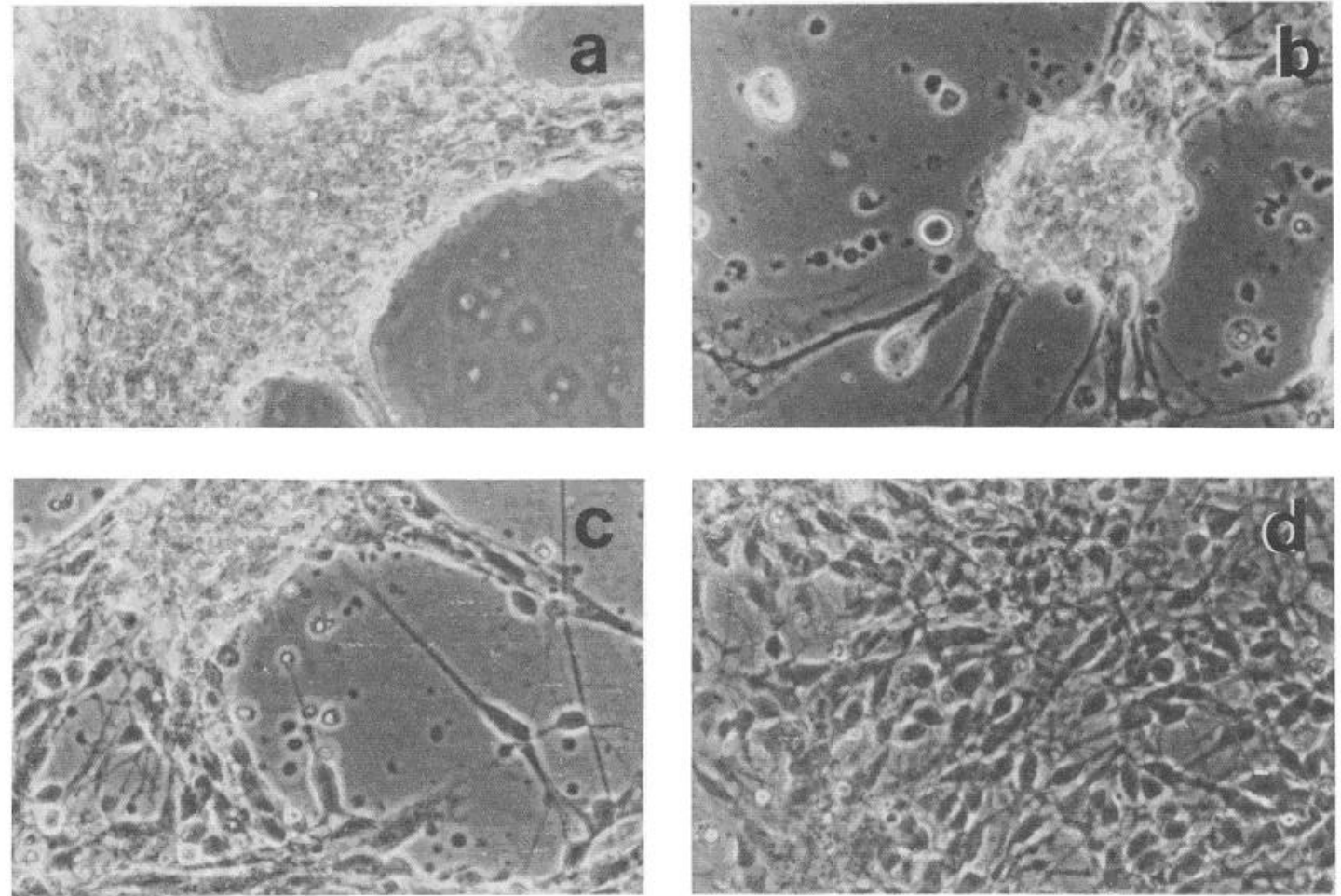

Figure 2. Attachment of postnatal cerebellar cells to microwells treated with varying concentrations of plasma fibronectin after $48 \mathrm{hr}$ in vitro. Cells dissociated from postnatal day 4 cerebellum were plated on microwells treated with carbodi-imide ( $100 \mu \mathrm{g} / \mathrm{ml})$ and $(a) 0,(b) 10,(c) 25$, or $(d) 50 \mu \mathrm{g} / \mathrm{ml}$ of fibronectin. Magnification $\times 160$.

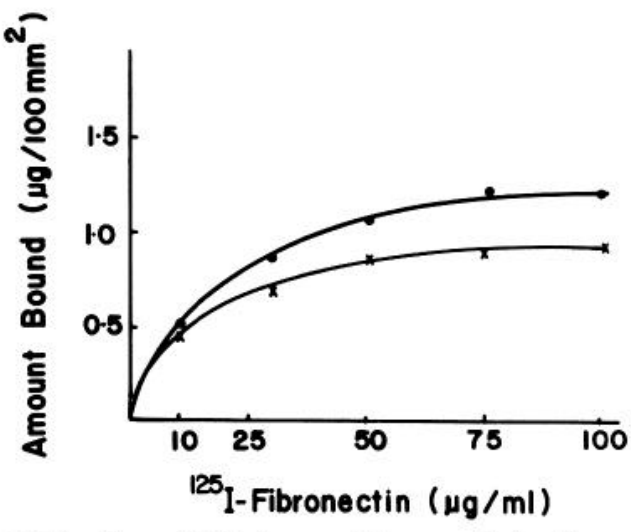

Figure 3. Binding of ${ }^{125} \mathrm{I}$-plasma fibronectin to tissue culture plastic. Plates were treated with ${ }^{125} \mathrm{I}$-plasma fibronectin (10 to $100 \mu \mathrm{g} / \mathrm{ml})$ and carbodi-imide $(100 \mu \mathrm{g} / \mathrm{ml}-0)$ or ${ }^{125} \mathrm{I}$ plasma fibronectin $(10$ to $100 \mu \mathrm{g} / \mathrm{ml} ; \mathrm{X}-\mathrm{X})$. After $2 \mathrm{hr}\left(20^{\circ} \mathrm{C}\right)$, the wells were rinsed three times with distilled water, air-dried, cut out, and counted with a Beckman Gamma 4000 counter.

peared to slow the release of bound fibronectin from the nicrowell surface.

The question then was raised as to whether carbodiimide was required for cerebellar cell adhesion to microwells coated with CIG. When late embryonic or early postnatal cerebellar cells were plated on microwells treated with fibronectin $(50 \mu \mathrm{g} / \mathrm{ml})$ in the presence or absence of carbodi-imide $(100 \mu \mathrm{g} / \mathrm{ml})$, identical results were observed for the first 24 to $48 \mathrm{hr}$ in vitro. After that time, however, especially after as much as 1 week in culture, late embryonic or early postnatal cerebellar cells

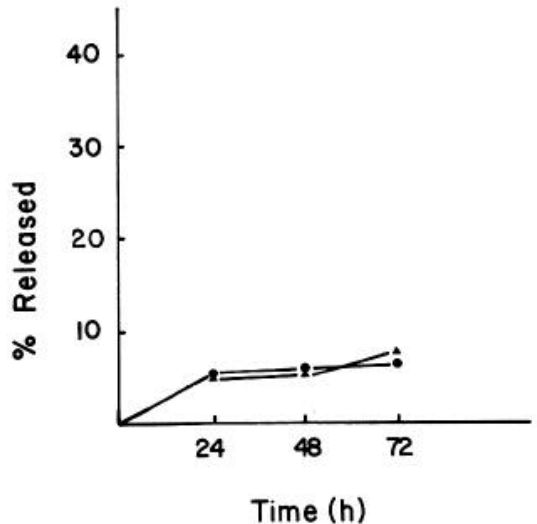

Figure 4. Release of bound ${ }^{125} \mathrm{I}$-plasma fibronectin from tissue culture dishes in the presence and absence of cerebellar cells. Microwells were treated with both carbodi-imide $(100 \mu \mathrm{g} / \mathrm{ml})$ and ${ }^{125} \mathrm{I}$-plasma fibronectin $(50 \mu \mathrm{g} / \mathrm{ml})$. $\longrightarrow$, Microwells incubated with complete culture medium; $\mathbf{\Delta}-\mathbf{\Lambda}$, microwells plated with P0 cerebellar cells $\left(2 \times 10^{6}\right.$ cells $\left./ \mathrm{ml}\right)$ as described. After the time indicated, the medium was removed and counted, precipitated with $10 \% \mathrm{TCA}\left(4^{\circ} \mathrm{C}, 30 \mathrm{~min}\right)$ in the presence of BSA $(1 \mathrm{mg} / \mathrm{ml})$, and counted again. The microculture well was cut out and counted. Total counts were obtained by adding the counts on the dish and the counts in the medium prior to TCA precipitation. The percentage of counts released was calculated by dividing TCA-precipitable counts in the medium by the total counts. Less than $3 \%$ free ${ }^{125} \mathrm{I}$ was present in the starting solution of ${ }^{125} \mathrm{I}$-plasma fibronectin.

sometimes detached from culture dishes treated with fibronectin alone. Treating microwells with both fibronectin and carbodi-imide supported cerebellar cell adhe- 
sion for 2 to 4 weeks when the medium was changed every 3 days.

Co-treatment of the microwell surfaces with carbodiimide and fibronectin was used for most cell culture studies, because it lengthened the time period that the cells remained attached to the dish, presumably by slowing the leakage of bound fibronectin from the microwell surface. Thus, carbodi-imide facilitated long term studies of cerebellar cell behavior on a fibronectin-coated microwell surface, but it was not necessary per se for cerebellar cell adhesion to fibronectin.

It is possible that co-treatment of the microwell surfaces with fibronectin and carbodi-imide altered the binding properties of the fibronectin substratum used for adhesion assays. We find this interpretation unlikely, because the same results were observed with microwells treated with fibronectin in the presence and absence of carbodi-imide and because carbodi-imide treatment did not affect the specific inhibition by AbCIG of cerebellar cell adhesion to a fibronectin-treated substratum. This interpretation is supported by previous studies indicating that carbodi-imide cross-links proteins to nylon fibers or to tissue culture plastic without altering their specific binding characteristics (Edelman and Rutishauser, 1974; Hatten and Francois, 1981).

To assess whether postnatal cerebellar cells degraded the fibronectin substratum, P0 cells were plated on microwells treated with ${ }^{125} \mathrm{I}$-fibronectin $(50 \mu \mathrm{g} / \mathrm{ml})$ and carbodi-imide $(100 \mu \mathrm{g} / \mathrm{ml})$. Less than $10 \%$ of the bound ${ }^{125} \mathrm{I}$ fibronectin was released into the culture medium over a 48-hr period in vitro (Fig. 4). Of the fibronectin released into the medium, 60 to $85 \%$ of the counts were precipitated by TCA (10\%). The remaining counts were presumably free ${ }^{125} \mathrm{I}$ or ${ }^{125}$ I-peptides.

The adhesion of dissociated postnatal cerebellar cells to microwell surfaces treated with plasma fibronectin and carbodi-imide was inhibited by antiserum raised against human CIG (AbCIG). When the antiserum was added to the growth medium, the degree of inhibition depended on the dilution of the antiserum (Fig. 5). Maximal inhibition occurred at a dilution of 1:50. Antisera against BSA at dilutions ranging from 1:10 to 1:500 had no effect on cerebellar cell adhesion to fibronectintreated microwell surfaces.

The inhibition of cell adhesion to fibronectin by soluble AbCIG was reversible if the antibody was removed by washing the cultures three times with PBS and replaced with fresh growth medium within the first $24 \mathrm{hr}$ after plating. After that time, removal of the antiserum induced a few cells to attach to the substratum, but considerable cell degeneration was evident in the cultures as judged by phase contrast microscopy (data not shown).

Cell attachment also was inhibited $(60 \%)$ when cells were plated on a fibronectin-coated substratum that had been pretreated with AbCIG (1:50). This result was independent of whether plasma fibronectin was present in the horse serum supplement to the growth medium. Cell attachment was not inhibited when the cell suspension was pretreated with AbCIG (1:50), washed three times with PBS, and then plated on a fibronectin-coated substratum in medium supplemented with horse serum or with horse serum depleted of plasma fibronectin. Thus, the effect of AbCIG to cell attachment appeared to be on the substratum rather than on the cells.

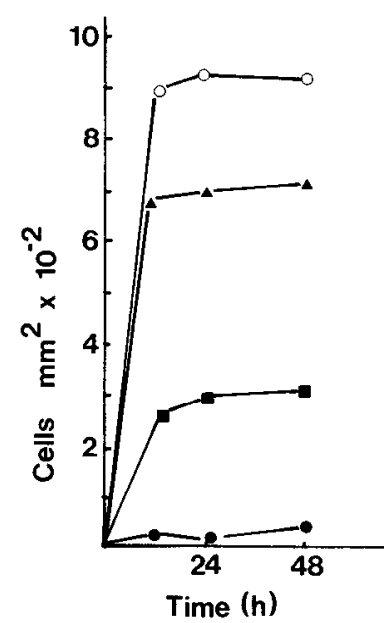

Figure 5. Inhibition of attachment of postnatal cerebellar cells to insoluble fibronectin by free AbCIG. P5 cerebellar cells $\left(2 \times 10^{6} / \mathrm{ml}\right)$ were plated on microwells treated with carbodiimide $(100 \mu \mathrm{g} / \mathrm{ml})$ and plasma fibronectin $(50 \mu \mathrm{g} / \mathrm{ml})$ as described in the absence or in the presence of AbCIG. After 2, 12, 24 , or $48 \mathrm{hr}$ in vitro, the cultures were washed three times with PBS to remove any debris and the number of cells per $\mathrm{mm}^{2}$ was counted by phase contrast microscopy. The final dilution of $\mathrm{AbCIG}$ in the medium was $0(\mathrm{O}-\mathrm{O}), 1: 200(\mathbf{\Delta}-\mathbf{A}), 1: 100$ (ㅁ) or $1: 50(\mathbf{O})$ ).

Time-lapse video recordings of postnatal cerebellar cells plated on a fibronectin substratum revealed extensive cell movement in the cultures (Fig. 6). At least two types of cell movement were observed. First, some individual cells moved independently on the substratum. Second, other cells moved along processes present in the culture. Both types of movement were evident over the range of cell densities studied. At higher plating densities, small cellular aggregates were present in addition to monolayer regions. These aggregates also moved about on the fibronectin substratum. It was not possible by light microscopy to follow the movements of single cells within aggregates.

The movement of single cells did not always occur at a uniform, continuous rate. Whereas, some cells moved at a rate of approximately $10 \mu \mathrm{m} / \mathrm{hr}$, other cells had rapid, sudden movements at rates up to $200 \mu \mathrm{m} / \mathrm{hr}$. With phase contrast microscopy, there was no clear morphological distinction between fast and slow moving cells, and indeed, the same cell often would exhibit both types of movement. Fast movements did, however, seem to be more typical of cells moving along processes.

Immunocytochemical localization of fibronectin in tissue sections. Indirect cytochemical staining of tissue sections with antisera raised against CIG revealed a developmentally regulated pattern of endogenous fibronectin. At E13, dense, diffuse, specific staining with AbCIG occurred at the ventral portion of the neuroepithelium, the site of emergence of the first precursor granule cells (Fig. 7, $a, b$, and $c$ ). The choroid plexus, not visible in the photograph of the section in Figure $7 b$, also was intensely stained. Intermittent patches of intense, specific staining with AbCIG were visible in the EGL itself, which had just begun to emerge on the external surface of the cerebellar plate. No specific staining of the neuroepithelium lining the fourth ventricle or of the cerebellar plate was visible (data not shown). 



Figure 6. Movement of postnatal cells on insoluble plasma fibronectin. P0 cells were plated at $2 \times 10^{6}$ cells $/ \mathrm{ml}$. After $24 \mathrm{hr}$ in vitro, the movement of cells was assessed by phase contrast microscopy with time-lapse video recording as described. Photographs of the same field were taken from the video tape after $(a) 2,(b) 4,(c) 16$, and $(d) 18 \mathrm{hr}$. Magnification $\times 170$. In $a$ and $b$, one cell is marked with an arrow to visualize its movement over the 2-hr time period. Extensive movements of other cells in the field are evident as well. In $c$, many of the cells present in $a$ and $b$ have moved out of the field and have been replaced by other cells. The position of one cell is marked with a small arrow to visualize its movement in the 2-hr time lapse between $c$ and $d$. A larger arrow is used to point out a vacant space in $c$ into which the cell marked with the larger arrow in $d$ moves during this time span. Movements of other cells in the field are also evident.

At E16, the region of intense staining with AbCIG extended from the thickened ependyma adjacent to the choroid plexus across approximately one-third of the ventral surface of the cerebellar anlage. The choroid plexus also was brightly stained (data not shown). Although the dense band of staining was confined to the ventral portion of the cerebellum between the ependymal border and the pial surface, intermittent patches of staining were visible in the EGL, which was now forming and covered 60 to $80 \%$ of the surface of the cerebellar anlage. Very weak staining was visible in the developing cortical region of the cerebellum.

At $\mathrm{P} 0$, the region of intense, specific staining with AbCIG observed at E16 persisted over the ventral portion of the cerebellum between the choroid plexus, which was brightly stained, and the external surface (Fig. 7, $e$ and f). Intermittent patches of intense staining were evident in the EGL stretching across the surface of the cerebellum, but the dense region of specific staining was confined to the area along the interface with the developing brainstem. Weak staining of the cortical region (Fig. $7 f$ ) and some staining of the pial membrane was observed.
At P7, patches of staining with AbCIG were visible between the folia (Fig. 7, $i, j$, and $k$ ). The choroid plexus also was stained (data not shown). The region of intense, specific staining with AbCIG present at earlier stages at the lateral caudal edge of the cerebellar ependyma was no longer present. Weak staining of the molecular layer and the Purkinje cell layer also were seen. No specific staining of adult cerebellar tissue was observed with AbCIG (Fig. 8, $a$ and $b$ ).

The specificity of antibody binding was assessed by staining the sections either with AbCIG preabsorbed with CIG or with preimmune serum as described. Very little nonspecific binding was observed for any of the ages studied (Fig. 7). Therefore, the fluorescence observed would appear to be specific for fibronectin or a glycoprotein that shares antigenic determinants with fibronectin.

\section{Discussion}

The present studies suggest that a dense region of fibronectin is present along the pathway taken by proliferating granule cells from the ventricular surface of the neuroepithelium, where they are generated, across the 

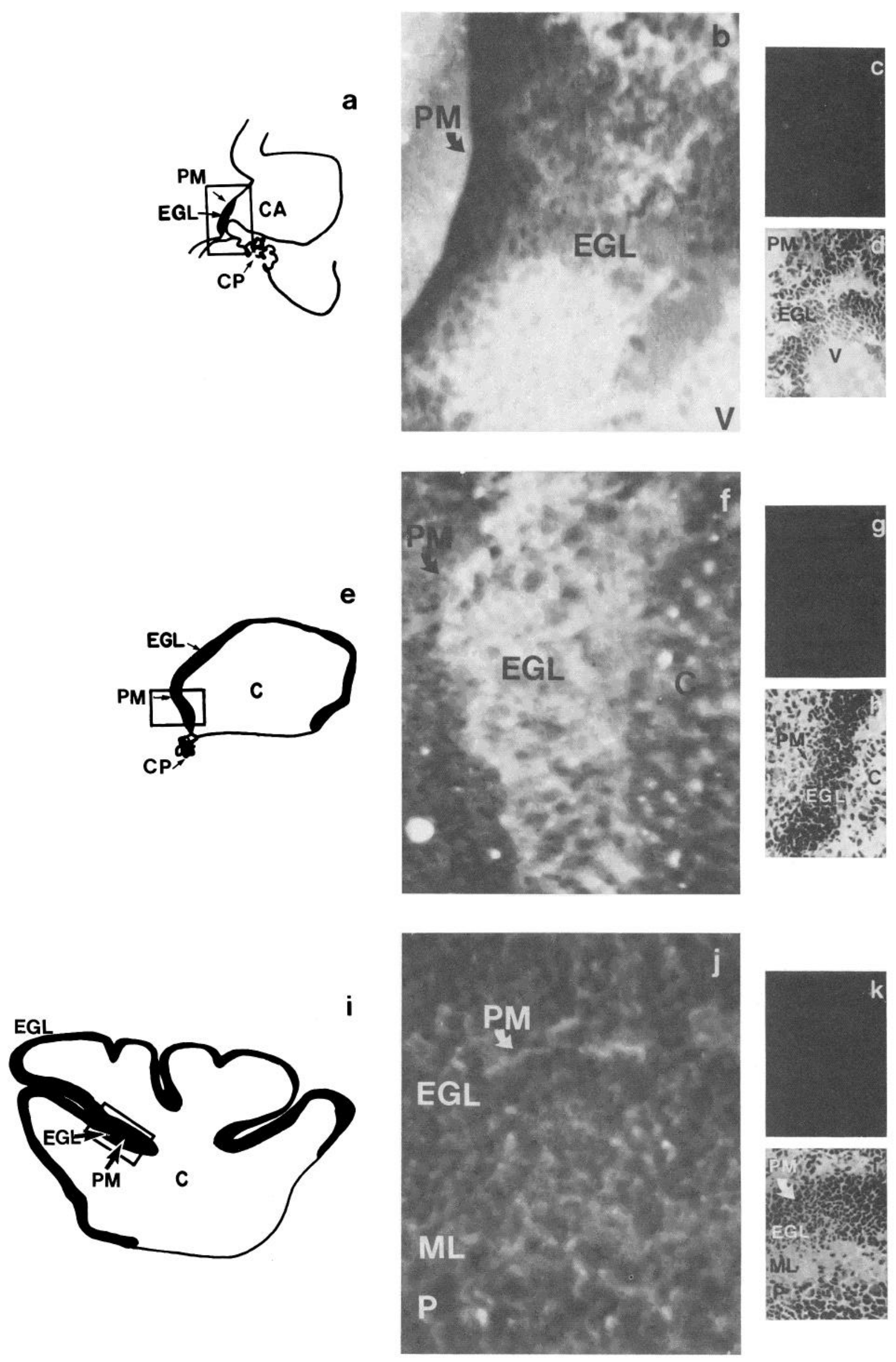

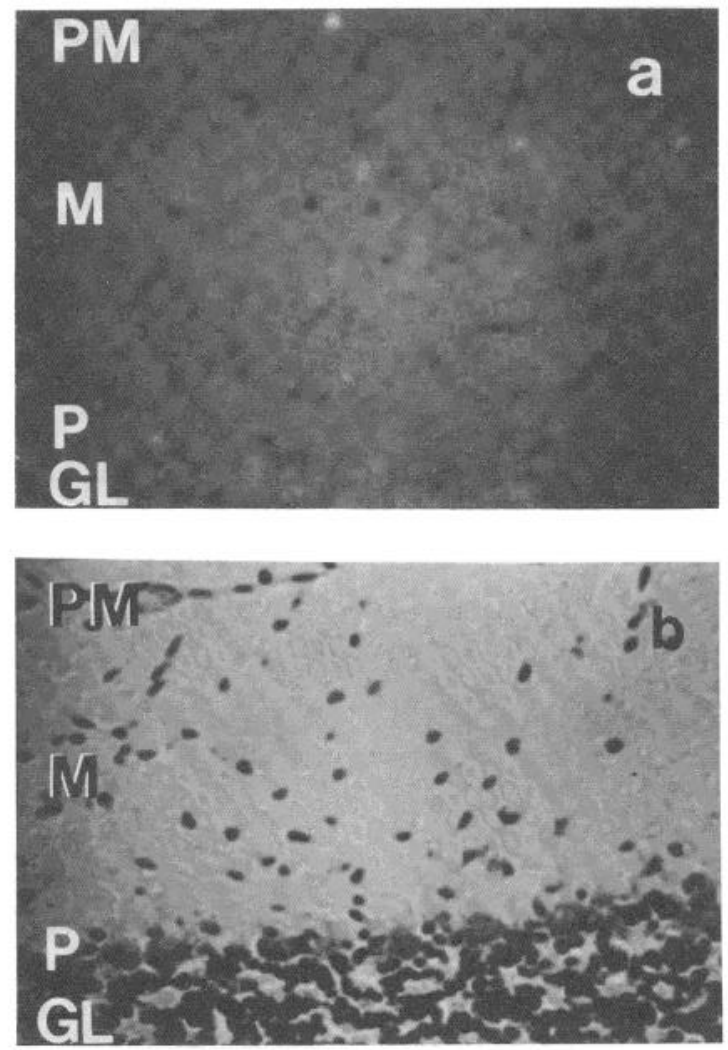

Figure 8. Binding of AbCIG to adult cerebellum (a). The same area in another section in the series was stained with toluidine blue $(b)$. Fluorescence was recorded with an image intensifier video camera and photographs were made from the television monitor. $P M$, Pial membrane; $M$, molecular layer; $P$, Purkinje cell layer; $G L$, granule cell layer. Details are given in the text. Magnification $\times 170$.

rhombic lip onto the external surface of the cerebellum and suggest a model for the formation of the EGL in the mouse cerebellum (presented schematically in Fig. 9).

The role of fibronectin in the forward area of the EGL is not clear. It might guide the cells to the anteromedial part of the cerebellum or it might simply be carried along by the cells after they pass through the region of dense fibronectin at the rhombic lip. After the EGL is formed, the dense region of fibronectin between the ventricular surface and the external surface is no longer needed and it disappears.

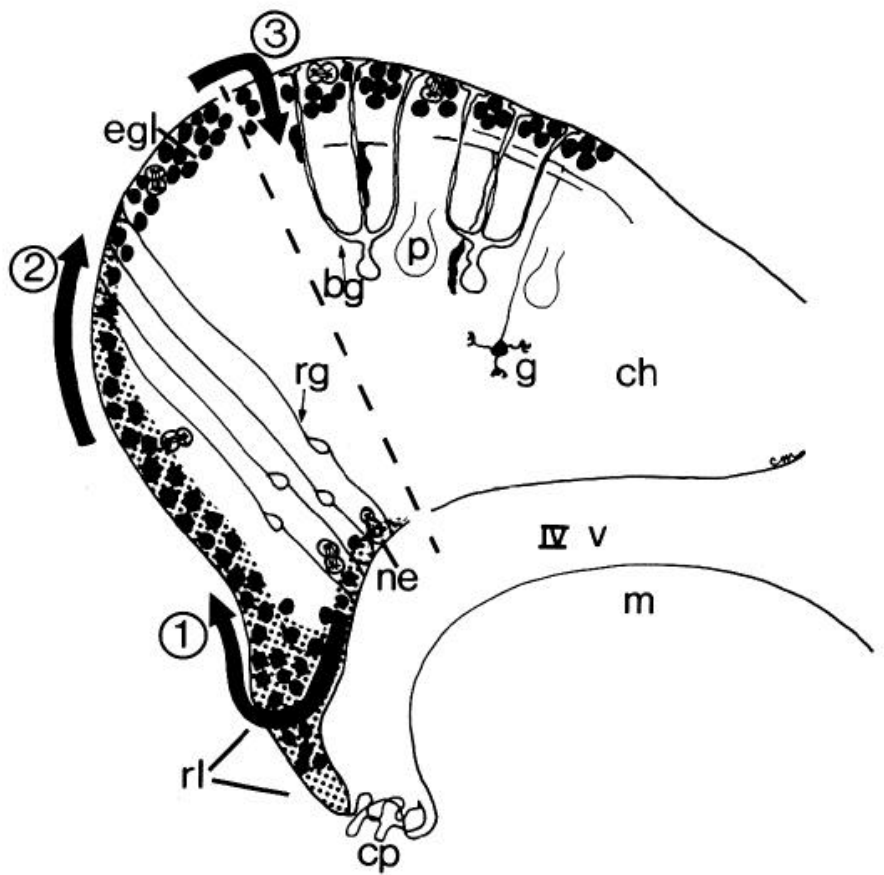

Figure 9. Schematic representation of the location of fibronectin in the embryonic mouse cerebellar anlage and the formation of the cerebellar external granular layer (EGL) in frontal view. 1, Proliferating, precursor granule cells (solid circles), both interphase and mitotic cells, move from the neuroepithelial surface (ne), where they are generated, across the rhombic lip $(r l)$ to the outer pial surface of the developing cerebellar anlage. A dense region of fibronectin (dotted region) is present across the rhombic lip which may facilitate the movement of proliferating, precursor granule cells to the outer surface. 2, A layer of proliferating, precursor granule cells (egl) spreads across the external surface of the developing cerebellum by the continued entry of cells at the rhombic lip. As the cells emerge from the dense region of fibronectin, they move across the surface among the end-feet of glial processes (radial $(\mathrm{rg})$ and/or Bergmann $(b g)$ ) until the entire surface is covered with proliferating granule cells. During this phase, which occurs between E13 and E16, patches of fibronectin are visible in the region occupied by glial end-feet. 3, After birth, postmitotic granule cells travel along Bergmann glial processes and descend into the deeper layers of the cortex where they mature $(g)$. Fibronectin staining is absent during this phase and therefore does not appear to play a role in this final step of granule cell migration. The dashed line separates pre- and postnatal events. $c p$, Choroid plexus; $I V V$, fourth ventricle; $c h$, cerebellar hemisphere; $p$, Purkinje cell; $m$, medulla.

Figure 7. The formation of the EGL in the developing mouse cerebellum and the binding of AbCIG. $a$, Drawing of the cerebellar anlage at E13. The EGL (shaded) has just begun to form. $b$ Staining of the area in the box ( $a$ ) with AbCIG. The ventral portion of the cerebellum adjacent to the ependymal site is intensely stained. In addition, patches of staining are visible at the EGL (lower right). The pial membrane $(P M)$ along the outer surface of the cerebellar anlage $(C A)$ and the fourth ventricle $(V)$ are marked for orientation. Control sections were stained with $(c)$ AbCIG preabsorbed with CIG and $(c)$ AbCIG preabsorbed with CIG and $(d)$ toluidine blue to reveal cell bodies. $C P$, Choroid plexus. $e$, Drawing of the cerebellum $(C)$ at P0. The EGL (shaded) now covers the entire surface of the cerebellum. $f$. Binding of AbCIG to the ventral portion of the neuroepithelium where the EGL originated (area shown in the box in $e$ ). Control sections were stained with (g) AbCIG preabsorbed with CIG and $(h)$ toluidine blue to reveal cell bodies. $i$, Drawing of the cerebellum $(C)$ at P7. Folia have started to form. The EGL (shaded area $)$ is visible along the external edges of the folia. The migration of cells from the EGL into the deep layers of the cerebellar cortex has begun. $j$, Staining of the area shown in the box in $i$ with AbCIG. Intermittent patches of staining along the pial membrane $(P M)$ in the folia as well as weak staining of the molecular layer $(M L)$ and Purkinje cell layer $(P)$ are visible. Control sections were stained with $(k)$ AbCIG preabsorbed with CIG and $(l)$ toluidine blue to reveal cell bodies. Fluorescence was recorded with an image intensifier video camera and the photographs were made from the television monitor. All photographs of fluorescence were printed under identical conditions. Magnification: $b, f$, and $j \times 260$; other photographs, $\times 130$. Details are given in the text. 
The model presented for the role of fibronectin in the migration of proliferating, precursor granule cells in the developing mouse cerebellum is consistent with other recent studies on the function of fibronectin in cell movements during early histogenesis of the nervous system. Newgreen and Thiery (1980) have shown that fibronectin plays a transient role in neural crest migration in the chick, Kurkinen et al. (1979) have suggested a role for fibronectin in the development of the eye, and Mayer et al. (1981) have localized fibronectin in the embryonic chick trunk and area vasculosa.

The presence of fibronectin in embryonic mouse cerebellum is supported by the studies of Kavinsky and Garber (1979) which showed that cells dissociated from mouse cerebellum at embryonic day 13 synthesized fibronectin when maintained in vitro. Schachner et al. (1978) reported staining of the choroid plexus and pia in embryonic mouse cerebellum but did not report staining of the lateral caudal region of the cerebellar anlage. As these workers did not present photographs of early embryonic material, it is difficult to assess the discrepancy with the present report. It is possible that they did not examine the rhombic lip region or that the fibronectin staining that we observed for embryonic cerebellum was facilitated by an image intensifier television camera. Schachner et al. (1978) also did not report the patches of fibronectin staining between the folia which we observed in mouse cerebellum and which Minier et al. (1981) recently reported for rat cerebellum. The absence of fibronectin staining in adult cerebellar tissue reported here is in agreement with both of these studies (Schachner et al., 1978; Minier et al., 1981).

A major issue, not addressed by these studies, will have to be resolved to provide a more detailed mechanism for granule cell migration, namely the source of AbCIG binding sites in embryonic mouse cerebellum. The present studies did not define the cellular source of the fibronectin, primarily because the intense area of fibronectin staining in embryonic cerebellar tissue was diffuse.

One possibility is that fibronectin is synthesized by astroglial cells (Vaheri et al., 1976; Kavinsky and Garber, 1979). The cell lineage of mature glia in the cerebellum is unclear at present. Recent studies have revealed that several types of glial cells are present in early embryonic cerebellum, radial glia across the rhombic lip, and possibly some forms of astroglia, including Bergmann glia, in the cerebellar anlage itsclf (Sommer et al., 1981; Levitt and Rakic, 1980). In the present study, the dense region of fibronectin staining occurs in the area thought to be occupied by radial glia (Levitt and Rakic, 1980; Z. Fulop and P. Rakic, personal communication) and ependymal cells, including cells of the choroid plexus. Whereas mature Bergmann glia probably do not synthesize fibronectin (Schachner et al., 1978; Schnitzer et al., 1981), it is possible that precursors of Bergmann glia or of astrocytes, radial glia, or even ependymal cells themselves synthesize fibronectin. Light microscopy at high magnification and electron microscopy in conjunction with the peroxidase-antiperoxidase or colloidal gold technique are presently being carried out to resolve this issue.
The specific adhesion of cells dissociated from cerebellar tissue between E16 and P7 to insoluble fibronectin is also consistent with the model presented for granule cell migration. The adhesion studies suggest that the cell surface properties involved in adhesion to fibronectin are acquired when the external granule cell layer forms (Miale and Sidman, 1961; Altman and Bayer, 1978).

At E13, although the region of dense fibronectin is in place, very few proliferating granule cells have migrated through this region out onto the pial surface. When the tissue is dissociated into a single cell suspension, 80 to $85 \%$ of the cells which survive in the microwell culture are granule cells (Hatten and Sidman, 1978; Hatten and Liem, 1981). Again, presumably only a small fraction of these granule cells have encountered the area of dense staining with AbCIG. The adhesion studies suggest that, at this stage, just prior to the formation of the EGL, cellcell adhesion among precursor granule cells occurs preferentially to cell-fibronectin adhesion and cellular aggregates are formed.

At E16, the EGL is forming and a large proportion of the proliferating granule cell population has migrated through the region intensely stained with AbCIG. When this tissue is dissociated and plated in microwell cultures, granule cells constitute 80 to $85 \%$ of the total cell population, again presumably because of the high viability of these cells in this culture system (M. E. Hatten, unpublished observation). At this stage, during the formation of the EGL, virtually all of the cells in the culture adhere to a fibronectin-coated substratum.

By birth, the EGL is formed and all of the precursor granule cells have passed through the region of intense staining with AbCIG. Virtually all of the cells dissociated from this tissue adhere to a fibronectin-coated substratum. Thus, we favor the interpretation that the adhesion studies presented here reveal a change in cell surface properties required for adhesion to fibronectin between E13 and E16.

Given the disappearance of endogenous fibronectin after birth, it was of interest that cells dissociated as late as postnatal day 7 attached to insoluble fibronectin. Recent studies suggest that, on adhesive substrata such as polylysine (Hatten and Liem, 1981) or certain lectins (M. E. Hatten and C. A. Mason, unpublished result), it is the astroglial processes which organize the position of neurons dissociated from postnatal cerebellum. It is possible therefore that the results with postnatal cells relate to the attachment of astroglia to the fibroncctin substratum, followed by the association of neurons with astroglial processes. This is supported by the recent observation of Morrison and deVellis (1981) that astroglial cells dissociated from cerebral cortex and maintained in culture extend processes when plated in a growth medium supplemented with fibronectin. Specific cell markers and electron microscopy presently are being used to identify which of the postnatal cerebellar cell types adhere to the fibronectin substratum.

At the embryonic ages studied here, in particular between E13 and E16 when the change in adhesive specificity to fibronectin occurs, the granule cells do not associate with astroglial cells and can bind directly to the 
substratum in microwell cultures (Hatten and Liem, 1981). Since the vast majority of cells in these cultures are precursor granule cells, it is likely that the results relate primarily to the adhesive specificity of granule cells. It is also likely that developing glial cells adhere to the fibronectin substratum at late embryonic periods, but this remains to be demonstrated with immunological markers and with electron microscopy.

The finding that dissociated cerebellar cells adhere to a fibronectin substratum agrees with the recent study of Akers et al. (1981) which showed the outgrowth of processes on a fibronectin-coated substratum by aggregates of embryonic chick neural retinal cells in vitro. The cellular source of the processes in the latter study have not yet been identified.

The present study suggests that fibronectin may play an important, transient role in the histogenesis of the mouse cerebellum, namely, to facilitate the migration of proliferating precursor granule cells from the ventricular surface of the neuroepithelium up onto the external surface of the cerebellar plate. Once the EGL has formed, the role of fibronectin is apparently fulfilled and specific cell contacts with Bergmann glial processes appear to guide the final positioning of postmitotic, granule cell neurons.

\section{References}

Akers, R. M., D. F. Mosher, and J. E. Lilien (1981) Promotion of retinal neurite outgrowth by substratum-bound fibronectin. Dev. Biol. 86: 179-188.

Alexander, S. S., Jr., G. Colonna, K. M. Yamada, I. Pastan, and H. Edelhoch (1978) Molecular properties of a major cell surface protein from chick embryo fibroblasts. J. Biol. Chem. 253: $5820-5824$.

Alexander, S. S., Jr., G. Colonna, and H. Edelhoch (1979) The structure and stability of human plasma cold-insoluble globulin. J. Biol. Chem. 254: 1501-1505.

Altman, J., and S. A. Bayer (1978) Prenatal development of the cerebellar system in the rat. I. Cytogenesis and histogenesis of the deep nuclei and the cortex of the cerebellum. J. Comp. Neurol. 145: 353-398.

Balian, G., E. Crouch, E. M. Click, W. G. Carter, and P. Bornstein (1979) Comparison of the structures of human fibronectin and plasma cold-insoluble globulin. J. Supramol. Struct. 12: 505-516.

Edelman, G. M., and U. Rutishauser (1974) Specific fractionation and manipulation of cells with chemically derivatized fibers and surfaces. Methods Enzymol. 34: 195-225.

Freeman, T. (1967) Trace labeling with radioiodine. In Handbook of Experimental Immunology, D. M. Weir, ed., pp. 297607, F. A. David Co., Philadelphia, PA.

Furie, M. B., and D. B. Rifkin (1980) Proteolytically derived fragments of human plasma fibronectin and their localization within the intact molecule. J. Biol. Chem. 255: 3134-3140.

Hatten, M. E. (1981) Cellular assembly patterns of embryonic mouse cerebellar cells on carbohydrate-derivatized polylysine culture substrata. J. Cell Biol. 89: 54-61.

Hatten, M. E., and A. M. Francois (1981) Adhesive specificity of developing cerebellar cells on lectin substrata. Dev. Biol. 87: $102-113$.

Hatten, M. E., and R. K. H. Liem (1981) Astroglia provide a template for the positioning of developing cerebellar cells in vitro. J. Cell Biol. 90: 622-630.

Hatten, M. E., and R. L. Sidman (1978) Cell reassociation hehavior and lectin-induced agglutination of embryonic mouse cells from different brain regions. Exp. Cell Res. 113: 111-125.

Hynes, R. O. (1976) Cell surface proteins and malignant transformation. Biochim. Biophys. Acta 458: 73-107.

Kavinsky, C. J., and B. B. Garber (1979) Fibronectin-associated with the glial component of embryonic brain cell cultures. J. Supramol. Struct. 11: 269-281.

Kurkinen, M., K. Alitalo, A. Vaheri, S. Stenman, and S. Saxen (1979) Fibronectin in the development of embryonic chick eye. Dev. Biol. 69: 589-600.

Levitt, S. P., and P. Rakic (1980) Immunoperoxidase localization of glial fibrillary acidic protein in radial glial cells and astrocytes of the developing rhesus monkey brain. J. Comp. Neurol. 193: 815-840.

Mayer, B. W., E. D. Hay, and R. O. Hynes (1981) Immunocytochemical localization of fibronectin in embryonic trunk and area vasculosa. Dev. Biol. 82: 267-286.

Mialc, I., and R. L. Sidman (1961) An autoradiographic analysis of histogenesis in the mouse cerebellum. Exp. Neurol. 4: 277296.

Minier, L. N., R. S. Lasher, and P. F. Erickson (1981) Distribution of the LETS protein (fibronectin) in rat cerebellum. Cell Tissue Res. 214: 491-500.

Morrison, R. S., and J. deVellis (1981) Growth of purified astrocytes in a chemically defined medium. Proc. Natl. Acad. Sci. U. S. A. 78: 7205-7209.

Newgreen, D., and J. -P. Thiery (1980) Fibronectin in early avian embryos: Synthesis and distribution along migration pathways of neural crest cells. Cell Tissue Res. 211: 269-291.

Palay, S., and V. Chan-Palay (1974) Cerebellar Cortex: Cytology and Organization, Springer, Berlin.

Pearlstein, E., L. L. Gold, and A. Garcia-Pardo (1980) Fibronectin: A review of its structure and biological activity. Mol. Cell. Biochem. 29: 103-128.

Rakic, P. (1971) Neuron-glia relationship during granule cell migration in developing cerebellar cortex. A Golgi and electron microscopic study in macacus rhesus. J. Comp. Neurol. 141: 283-312.

Rakic, P., and R. L. Sidman (1973) Sequence of developmental abnormalities leading to granule cell deficit in cerebellar cortex of Weaver mutant mice. J. Comp. Neurol. 152: 103132.

Rauvala, H., W. G. Carter, and S. -I. Hakomori (1981) Studies on cell adhesion and recognition. I. Extent and specificity of cell adhesion triggered by carbohydrate-reactive proteins (glycosidases and lectins) and by fibronectin. J. Cell Biol. 88: 127-137.

Ruoslahti, E., and A. Vaheri (1975) Interaction of soluble fibroblast surface antigen with fibrinogen and fibrin. Identity with cold insoluble globulin of human plasma. J. Exp. Med. 141: 497-501.

Schachner, M., G. Schoonmaker, and R. O. Hynes (1978) Cellular and subcellular localization of LETS protein in the nervous system. Brain Res. 158: 149-158.

Schnitzer, J., W. W. Franke, and M. Schachner (1981) Immunochemical demonstration of vimentin in astrocytes and ependymal cells of developing and adult mouse cerebellum. J. Cell Biol. 90: 435-447.

Sidman, R. L., and P. Rakic (1973) Neuronal migration with special reference to developing human brain: A review. Brain Res. 62: 1-35.

Sommer, I., C. Lagenaur, and M. Schachner (1981) Recognition of Bergmann glial and ependymal cells in the mouse nervous system by monoclonal antibody. J. Cell Biol. 90: 448-458.

Toole, B. P. (1976) Morphogenetic role of glycosaminoglycans in brain and other tissues. In Neuronal Recognition, S. H. 
Barondes, ed., pp. 275-329, Plenum Press, New York.

Trenkner, E., and R. L. Sidman (1977) Histogenesis of mouse cerebellum in microwell cultures. J. Cell Biol. 75: 915-940.

Vaheri, A., and D. F. Mosher (1978) High molecular weight, cell surface-associated glycoprotein (fibronectin) lost in malignant transformation. Biochim. Biophys. Acta 515: 1-25.

Vaheri, A., E. Ruoslahti, B. Westermark, and J. Poten (1976) A common cell-type specific surface antigen in cultured human glial cells and fibroblasts: Loss in malignant cells. J. Exp.
Med. 143: 64-72.

Vuento, M., M. Wrann, and E. Ruoslahti (1977) Similarity of fibronectins isolated from human plasma and spent fibroblast culture medium. FEBS Lett. 82: 227-331.

Yamada, K. M., and D. W. Kennedy (1979) Fibroblast cellular and plasma fibronectins are similar but not identical. J. Cell Biol. 80: 492-498.

Yamada, K. M., and K. Olden (1978) Fibronectin-adhesive glycoproteins of cell surface and blood. Nature 275: 179-184. 